Article

\title{
Investigation of the Antiproliferative Properties of Natural Sesquiterpenes from Artemisia asiatica and Onopordum acanthium on HL-60 Cells in Vitro
}

\author{
Judit Molnár ${ }^{1}$, Gábor J. Szebeni ${ }^{2}$, Boglárka Csupor-Löffler ${ }^{3}$, Zsuzsanna Hajdú ${ }^{3}$, \\ Thomas Szekeres ${ }^{4}$, Philipp Saiko ${ }^{4}$, Imre Ocsovszki ${ }^{5}$, László G. Puskás ${ }^{2}$, Judit Hohmann ${ }^{3}$ and \\ István Zupkó ${ }^{1, *}$ \\ 1 Department of Pharmacodynamics and Biopharmacy, University of Szeged, H-6720 Szeged, Hungary; \\ molnar.judit@pharm.u-szeged.hu \\ 2 AVIDIN Ltd., H-6726 Szeged, Hungary; g.szebeni@avidinbiotech.com (G.J.S.); \\ laszlo@avidinbiotech.com (L.G.P.) \\ 3 Department of Pharmacognosy, University of Szeged, H-6720 Szeged, Hungary; \\ csuporboglar@gmail.com (B.C.-L.); hajdu@pharm.u-szeged.hu (Z.H.); hohmann@pharm.u-szeged.hu (J.H.) \\ 4 Department of Medical and Chemical Laboratory Diagnostics, Medical University of Vienna, \\ A-1090 Vienna, Austria; thomas.szekeres@meduniwien.ac.at (T.S.); philipp.saiko@meduniwien.ac.at (P.S.) \\ 5 Department of Biochemistry, University of Szeged, H-6720 Szeged, Hungary; \\ ocsovszki.imre@med.u-szeged.hu \\ * Correspondence: zupko@pharm.u-szeged.hu; Tel.: +36-62-546-839; Fax: +36-62-545-567
}

Academic Editor: Marcello Iriti

Received: 27 October 2015; Accepted: 29 December 2015; Published: 17 February 2016

\begin{abstract}
Plants and plant extracts play a crucial role in the research into novel antineoplastic agents. Four sesquiterpene lactones, artecanin (1), $3 \beta$-chloro- $4 \alpha, 10 \alpha$-dihydroxy- $1 \alpha, 2 \alpha$-epoxy$5 \alpha, 7 \alpha H$-guaia-11(13)-en-12,6 $\alpha$-olide (2), iso-seco-tanapartholide 3-O-methyl ether (3) and $4 \beta, 15$-dihydro-3-dehydrozaluzanin C (4), were isolated from two traditionally used Asteraceae species (Onopordum acanthium and Artemisia asiatica). When tested for antiproliferative action on HL-60 leukemia cells, these compounds exhibited reasonable $\mathrm{IC}_{50}$ values in the range 3.6-13.5 $\mu \mathrm{M}$. Treatment with the tested compounds resulted in a cell cycle disturbance characterized by increases in the G1 and G2/M populations, while there was a decrease in the S phase. Additionally, 1-3 elicited increases in the hypodiploid (subG1) population. The compounds elicited concentration-dependent chromatin condensation and disruption of the membrane integrity, as revealed by Hoechst 33258-propidium staining. Treatment for $24 \mathrm{~h}$ resulted in significant increases in activity of caspases-3 and -9 , indicating that the tested sesquiterpenes induced the mitochondrial pathway of apoptosis. The proapoptotic properties of the sesquiterpene lactones were additionally demonstrated withannexin V staining. Compounds 1 and $\mathbf{2}$ increased the Bax/Bcl-2 expression and decreased the expressions of CDK1 and cyclin B2, as determined at the mRNA level by means of RT-PCR. These experimental results indicate that sesquiterpene lactones may be regarded as potential starting structures for the development of novel anticancer agents.
\end{abstract}

Keywords: sesquiterpenes; leukemia cells; cell cycle; apoptosis

\section{Introduction}

Cancerous disorders are the leading cause of death in economically developed areas of the world and the second cause of mortality in developing countries. In the developing world, the cancer burden is increasing as a result of multiple factors, including the adoption of a "westernized" lifestyle. In 2008, there were 12.4 million newly diagnosed cancers and 7.6 million cancer-related deaths worldwide, and 
it is estimated that these values will increase to 26.4 and 17 million, respectively, by 2030 [1]. Both the current state and the tendencies in the global cancer data clearly indicate that the preventive and therapeutic modalities utilized at present are suboptimal, and novel modes of intervention are called for, including innovative drugs with improved efficacy profiles.

The plant kingdom is a well-established and abundant source of drug candidates, and the systematic screening of plant preparations is therefore a widely accepted approach for the identification of original compounds with promising pharmacological properties. A number of the currently used anticancer drugs (e.g., Vinca alkaloids, podophyllotoxin analogs or taxanes) were discovered in ethnomedicinally fortified screening programs of higher plants [2]. The initially identified natural product frequently exhibits auspicious activity, but with poor pharmacokinetic properties, and chemical derivatization is needed to obtain novel analogs suitable for further drug development. A recent comprehensive analysis revealed that only $6 \%$ of the currently used drugs are unmodified natural products, whereas $27 \%$ of them are closely related to a natural prototype and a further $30 \%$ were designed on the basis of a natural pharmacophore element. Approximately two-thirds of the present therapeutic armamentarium is therefore naturally derived or inspired, and this is especially true in regard to concerns anticancer agents [3].

It is estimated that the plant kingdom numbers around 250,000 species, of which approximately $6 \%$ have been studied for biological activity, and about $15 \%$ phytochemically. The Asteraceae comprise one of the largest families of higher plants, with over 13,000 species worldwide [4]. From a phytochemical aspect, the members of the family are outstandingly rich in secondary metabolites, including sesquiterpene lactones, flavonoids, polyacetylenes, lignans and pentacyclic triterpene alcohols [5]. Since many of the plants of the family are used ethnomedicinally for a wide array of indications, including malignant disorders [6], but only limited data are available concerning the antiproliferative properties of the European species, a broad systematic screening program was earlier initiated by our group $[7,8]$. More than 400 extracts were prepared from 51 Asteraceae species found in Central and Eastern Europe and were tested for antiproliferative and cytostatic effects on human adherent cancer cell lines. As a continuation of this work, several of the active extracts were subjected to activity-guided fractionation and isolation of the constituents responsible for the detected antiproliferative action. This resulted in new natural products and also known substances described first from the investigated plant $[9,10]$. One of the recently investigated plants was Artemisia asiatica, which has been utilized in traditional Asian medicine for many diseases, including cancers. A formulated extract is available in South Korea for the treatment of gastroduodenal injuries, but its cancer-preventive activity has also been demonstrated in animal tumor models [11,12]. From an extract of the A. asiatica herb, two guaianolides, artecanin (1) and $3 \beta$-chloro- $4 \alpha, 10 \alpha$-dihydroxy- $1 \alpha, 2 \alpha$-epoxy- $5 \alpha, 7 \alpha H$-guaia-11(13)-en-12,6 $\alpha$-olide (2), and the seco-guaianolide iso-seco-tanapartholide 3-O-methyl ether (3) were recently isolated and demonstrated to exert antiproliferative actions against human adherent cancer cell lines [13]. Onopordum acanthium is another medicinal plant belonging in the Asteraceae family which has documented anticancer properties, and from this a fourth sesquiterpene lactone, $4 \beta, 15$-dihydro-3-dehydrozaluzanin $C(4)$, was isolated and tested in similar methods [14] (Figure 1).

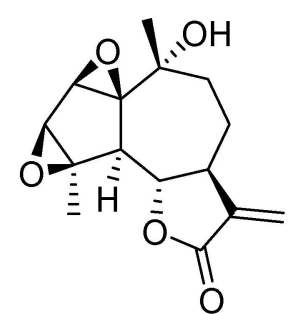

1

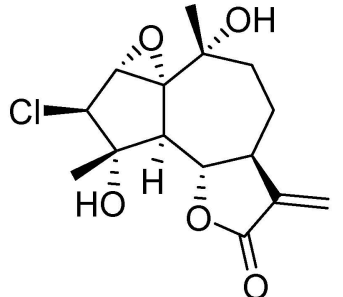

2

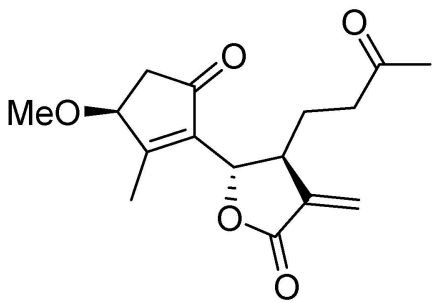

3

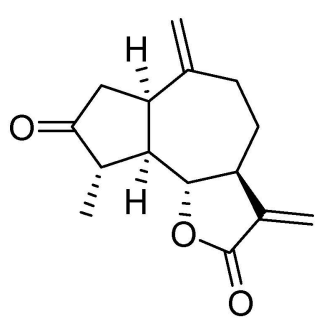

4

Figure 1. Chemical structures of the investigated sesquiterpenes. 
The aim of our current investigations was to extend the investigations of these sesquiterpenes by testing their activities on the growth of HL-60 human promyelocytic leukemia cells. The most potent agents were subjected to additional in vitro experiments in order to elucidate their mechanisms of action. A set of sesquiterpene lactones were earlier found to be more effective on HL-60 leukemia cells than against a panel of adherent cells [15].

\section{Results and Discussion}

\subsection{Antiproliferative Assay}

The antiproliferative effects of the tested sesquiterpenes were determined by counting HL-60 cells after 24, 48 and $72 \mathrm{~h}$ of exposure, and the 72-h results were used to calculate $\mathrm{IC}_{50}$ values (Figure 2). Compounds 3 and 4 proved to be more potent than $\mathbf{1}$ and 2, which is in good agreement with our previous data on adherent human cancer cell lines $[13,14]$.
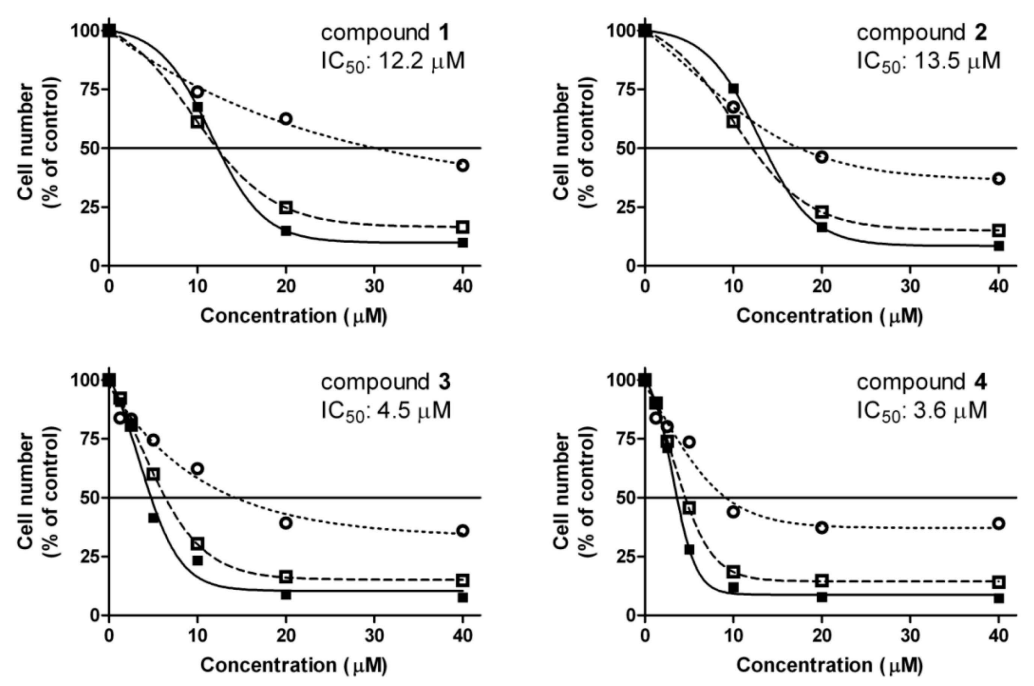

Figure 2. Concentration-response curves of 1-4 after incubation for $24(\mathbf{O}), 48(\boldsymbol{\square})$ and $72 \mathrm{~h}(\boldsymbol{\square})$ and their $\mathrm{IC}_{50}$ values calculated from 72 -h data. Data are means \pm SEM from three experiments.

\subsection{Cell Viability Measurements}

The cancer selectivities of $\mathbf{1}$ and $\mathbf{2}$ were characterized by means of MTS viability assays after $72 \mathrm{~h}$ of incubation against HL-60 and fibroblasts (Figure 3). Both of the tested sesquiterpenes exerted substantially more pronounced antiproliferative action against HL-60 than fibroblasts, indicating selective inhibition of cancer cell proliferation.


Figure 3. Concentration-response curves of $\mathbf{1}$ and $\mathbf{2}$ after incubation for $72 \mathrm{~h}$, and their calculated $\mathrm{IC}_{50}$ values. $\boldsymbol{\square}$ and $\boldsymbol{\square}$ indicate fibroblast and HL-60 cells, respectively. Data are means \pm SEM from three experiments. 


\subsection{Cell Cycle Analysis}

The effects of the tested compounds on the cell cycle distribution were determined by means of flow cytometry. HL-60 cells were treated with the compounds at 5 and $10 \mu \mathrm{M}$ for 24 and $48 \mathrm{~h}$ and the cell populations in the various cell cycle phases (subG1, G1, S and G2/M) were measured.

Each of the four sesquiterpenes caused a concentration-dependent disturbance of the cell cycle distribution (Figures 4 and 5). In general, the most pronounced results of treatment were increases in the G1 and G2/M populations, while the number of cells in the $\mathrm{S}$ phase was decreased. The action on the G2/M population was typically more substantial after $48 \mathrm{~h}$ than after $24 \mathrm{~h}$ of incubation, which could indicate a cell cycle arrest at the G2/M phase. The hypodiploid (subG1) population was additionally determined and a concentration and exposure-dependent increase was observed after $48 \mathrm{~h}$ of incubation. This latter action was a pronounced exception for 4 (Figure 6). Shorter ( $24 \mathrm{~h}$ ) exposure did not result in a substantial increase in subG1 cells (data not shown).
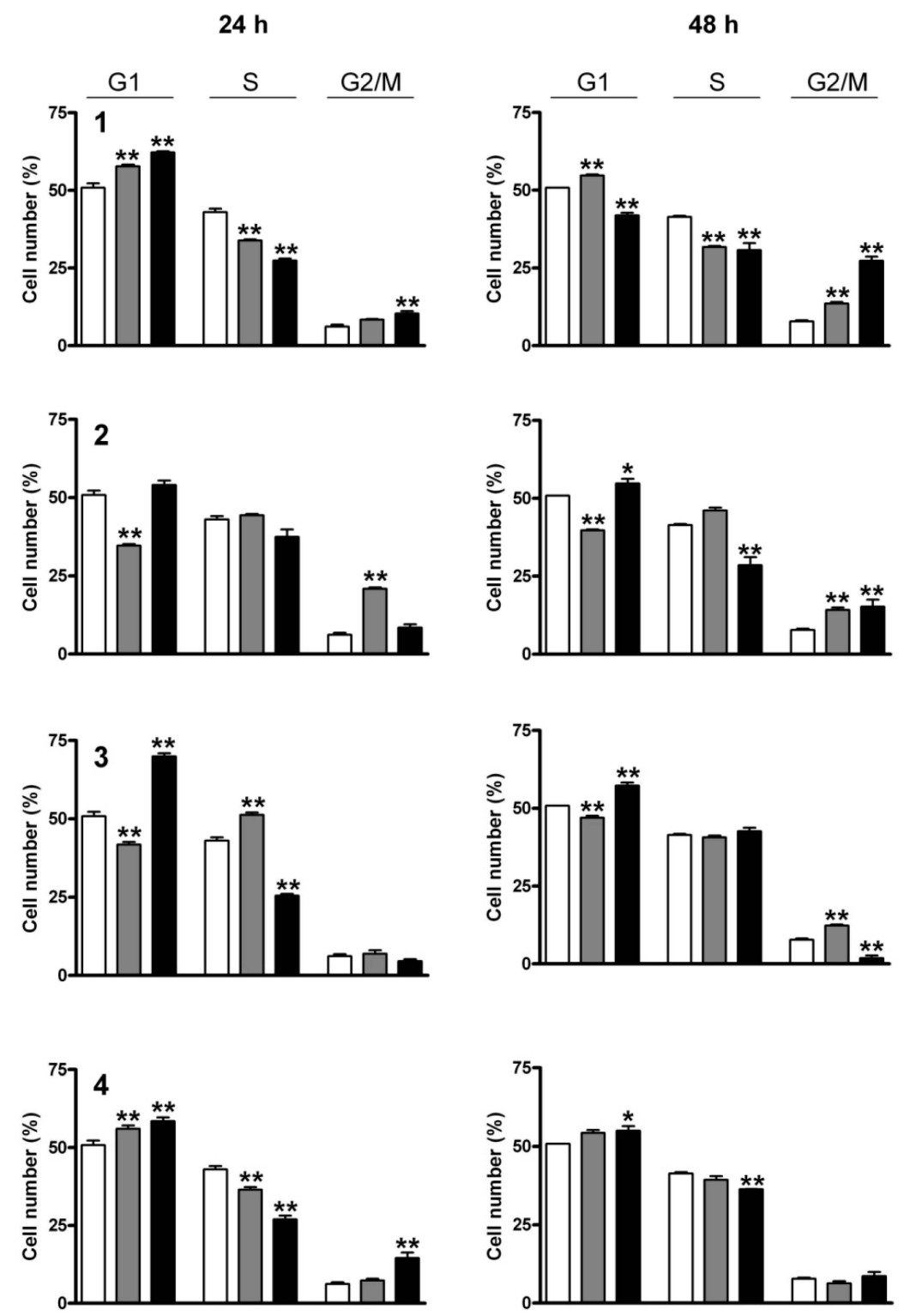

Figure 4. Cell-cycle distributions of HL-60 cells after treatment with 1-4 for 24 and $48 \mathrm{~h}$. Open, gray and black columns indicate data from control cells and cells treated with 5 or $10 \mu \mathrm{M}$ test substance, respectively. ${ }^{*}$ and ${ }^{* *}$ denote $p<0.05$ and $p<0.01$, respectively, as compared with the control condition. Data are means \pm SEM from three determinations. 


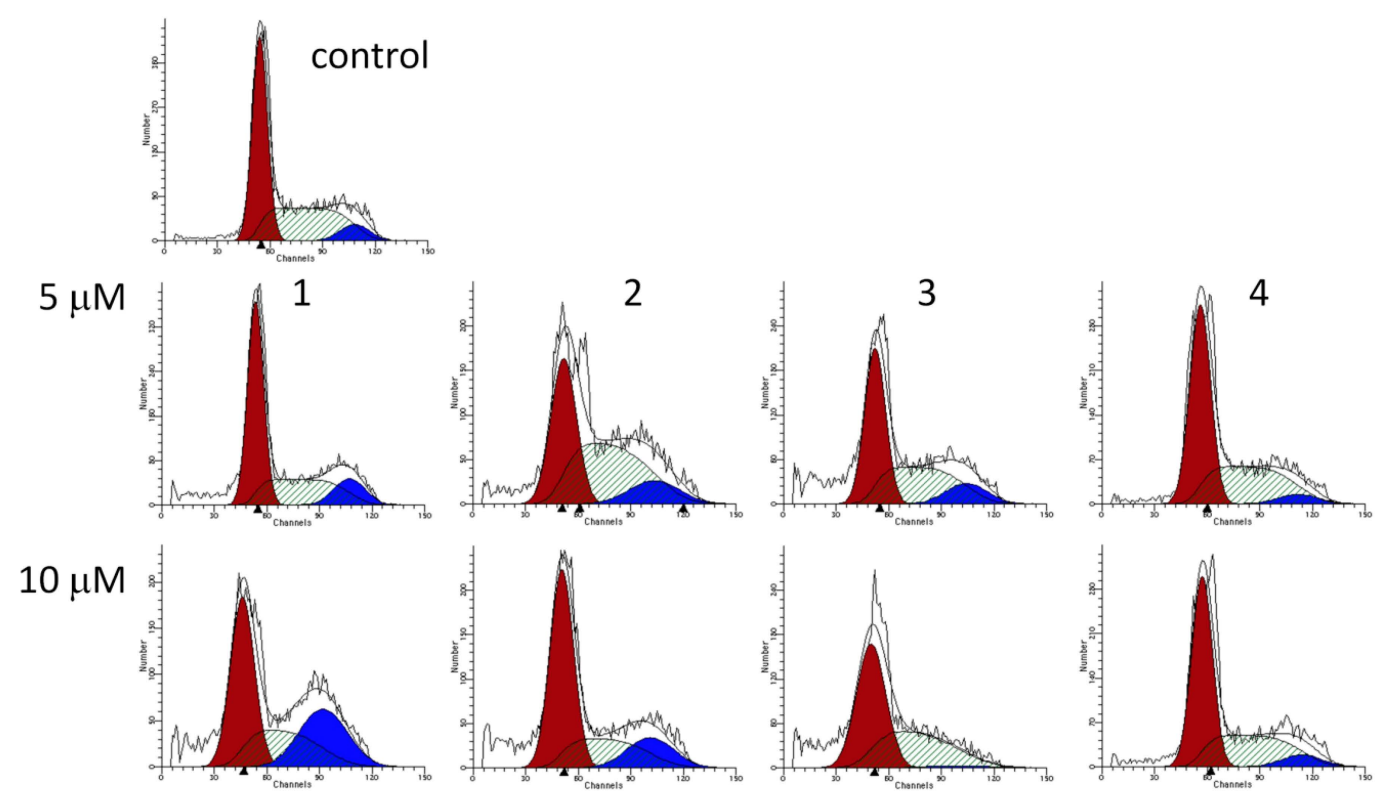

Figure 5. Representative cell-cycle histograms of control HL-60 cells after treatment with 5 or $10 \mu \mathrm{M}$ 1-4 for $48 \mathrm{~h}$.
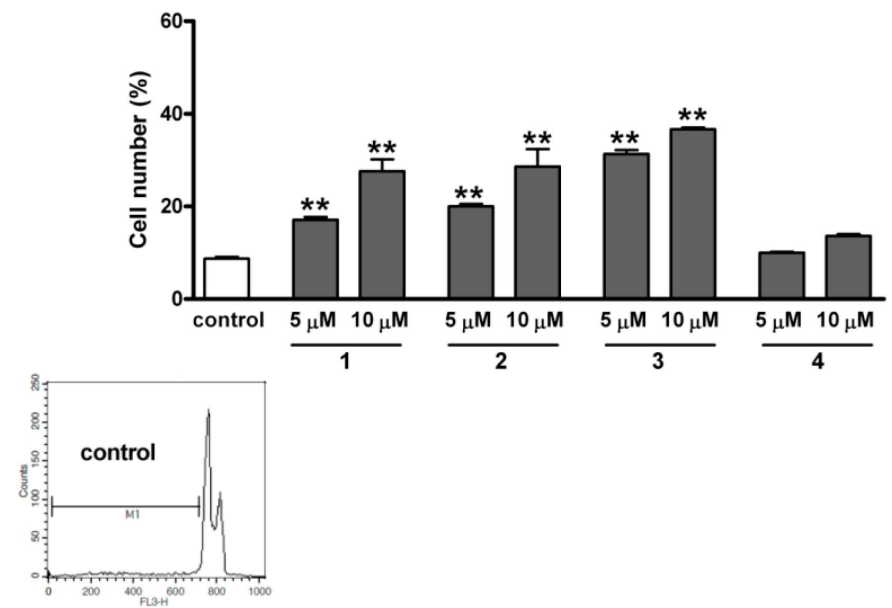

1

$5 \mu \mathrm{M}$
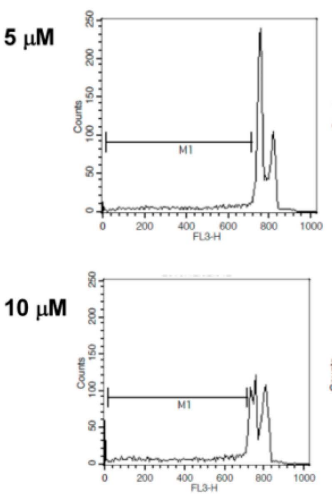

2


3
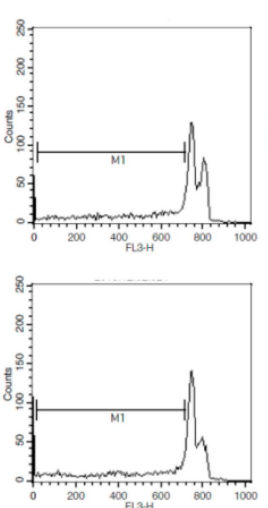

4


Figure 6. Hypodiploid (subG1) population of HL-60 cells after treatment with 1-4 for $48 \mathrm{~h}$ (upper panel). ${ }^{* *}$ denotes $p<0.01$ as compared with the control condition. Data are means \pm SEM from three determinations. Histograms representing the same conditions (lower panel). 


\subsection{Fluorescent Staining}

HL-60 cells were incubated with 5 and $10 \mu \mathrm{M}$ sesquiterpenes for 24 and $48 \mathrm{~h}$ and double-stained with fluorescent DNA markers (Hoechst 33258 and propidium iodide (PI)) to evaluate the morphological consequences. More intensive staining with Hoechst 33258 can be interpreted as a consequence of nuclear condensation. Separate pictures were taken illustrating the Hoechst 33258 and PI fluorescence as morphological markers. The extents of nuclear fragmentation and condensation were concentration-dependent for all four natural products after both incubation times, but were relatively independent of time after $24 \mathrm{~h}$ (Figure 7). Treatment-related impairment of the membrane function was detected using more intense PI staining, which was concentration- and exposure-dependent. Treatment with 3 or 4 resulted in profoundly disturbed membrane permeability, indicating a higher contribution of necrosis induction.
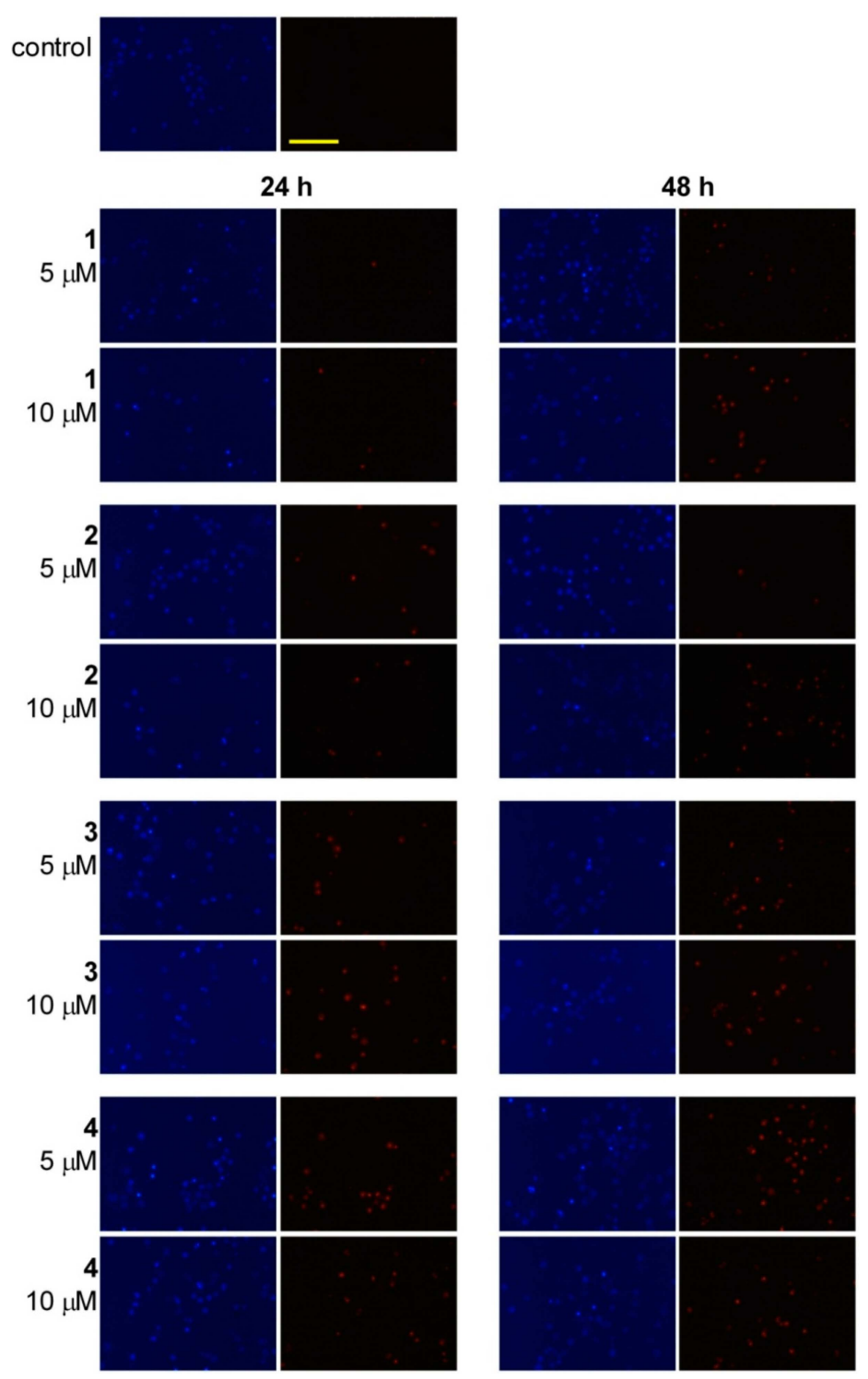

Figure 7. Fluorescence microscopic images of sesquiterpenes 1-4 after incubation for 24 and $48 \mathrm{~h}$. Two separate pictures from the same field were taken for the two markers. The blue fluorescence (left panels) relates to Hoechst 33258, and the red coloration (right panels) reflects cellular PI accumulation. The bar in the PI control picture indicates $100 \mu \mathrm{m}$. 


\subsection{Determination of Caspase-3 and Caspase-9 Activities}

Most of the current drugs applied in tumor therapy have the capacity to initiate apoptotic cell death, and the resultant controlled self-disassembly of the cancer cell is more advantageous to the surrounding intact cells than if necrosis occurs. A potential anticancer lead compound is expected to induce programmed cell death by modifying the balance between apoptotic and antiapoptotic signaling. Demonstration of a proapoptotic property is therefore a crucial part of the investigation of a novel potential antiproliferative drug candidate [16]. Although an increase in the subG1 population is also a generally accepted marker of apoptosis, one of the most reliable indicators of this is activation of the specific enzymes involved in the controlled cellular decomposition.

Caspases are cysteinyl aspartate proteases with elementary functions in the apoptotic machinery. The 18 mammalian caspases are classified as initiator or executioner caspases according to their role in the procedure [17].

Since no substantial incubation time-dependent differences were revealed by cell cycle analysis and fluorescence microscopy after $24 \mathrm{~h}$, the activities of the crucial caspases were determined only after a 24-h exposure. All four sesquiterpenes resulted in a significant increase in the activity of the main executionary isoenzyme caspase-3, the effects of 1 and $\mathbf{2}$ proving more pronounced (Figure 7 ). In the cases of 3 and 4, the action at $10 \mu \mathrm{M}$ was less marked than that at $5 \mu \mathrm{M}$. 1-4 all increased the activity of caspase-9, the initiator enzyme of the intrinsic pathway of apoptosis [17], though less extensively than in the case of caspase-3 (Figure 8). Caspase- 9 is the first element in a cascade, whereas caspase- 3 is a terminal element, i.e., a product of amplification.
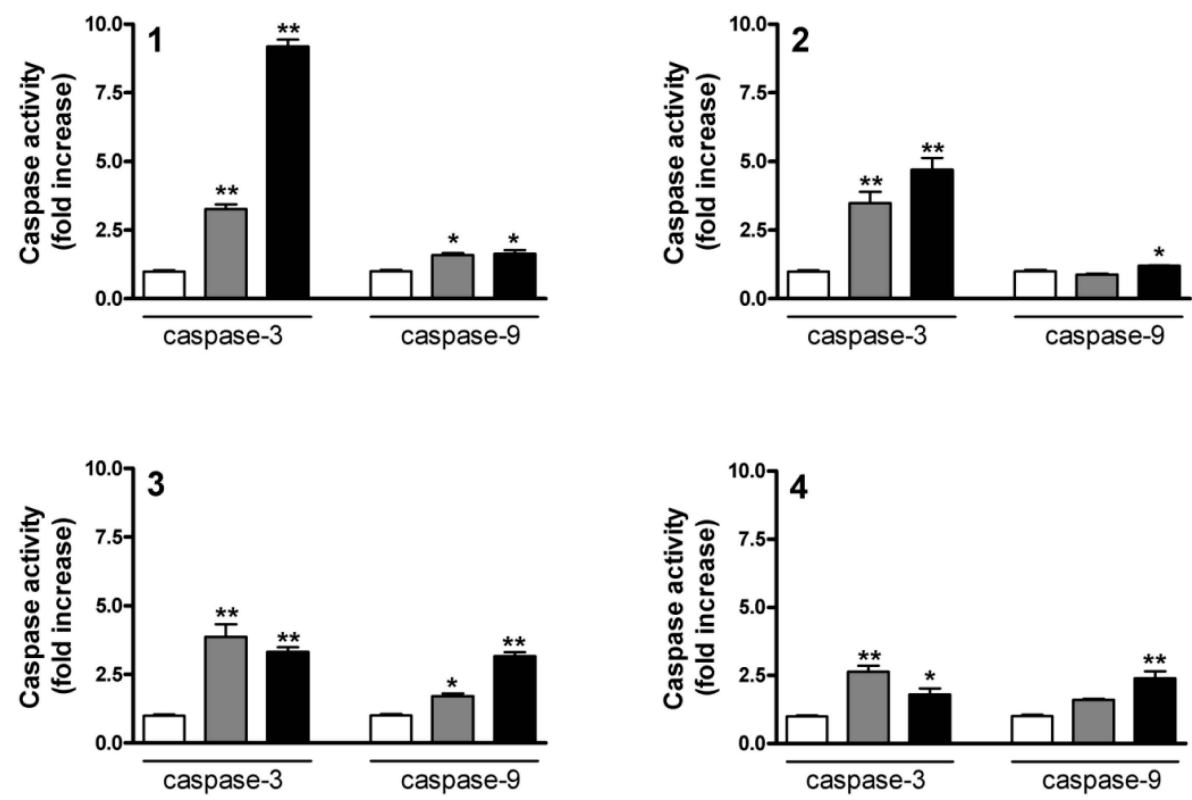

Figure 8. Induction of caspase-3 and caspase- 9 activities after incubation with compounds 1-4 for $24 \mathrm{~h}$. White, gray and black columns denote the control, or 5 and $10 \mu \mathrm{M}$ sesquiterpene, respectively. * and ${ }^{* *}$ denote $p<0.05$ and $p<0.01$, respectively, as compared with the control condition. The activities of caspase- 3 and caspase- 9 were determined with fluorimetric and colorimetric assay kits, respectively. Data are means \pm SEM from three determinations.

\subsection{Flow Cytometric Apoptosis Assay}

The proapoptotic potentials of 1-4 were further investigated by means of annexin V-Alexa 488 and PI staining, followed by flow cytometry. Treatment with each of the natural products resulted in concentration- and time-dependent increases in annexin V-positive cells (Figure 9). 1-4 elicited significant increases after $24 \mathrm{~h}$ of treatment, even at the lowest concentration used $(5 \mu \mathrm{M})$. Annexin 
V positivity indicates the loss of physiological phospholipid asymmetry maintained by the enzyme aminophospholipid translocase. During the early stages of programmed cell death, phosphatidylserine is exposed to the outer surface of the cell membrane and this phenomenon is considered to be a biochemical apoptotic marker [18].
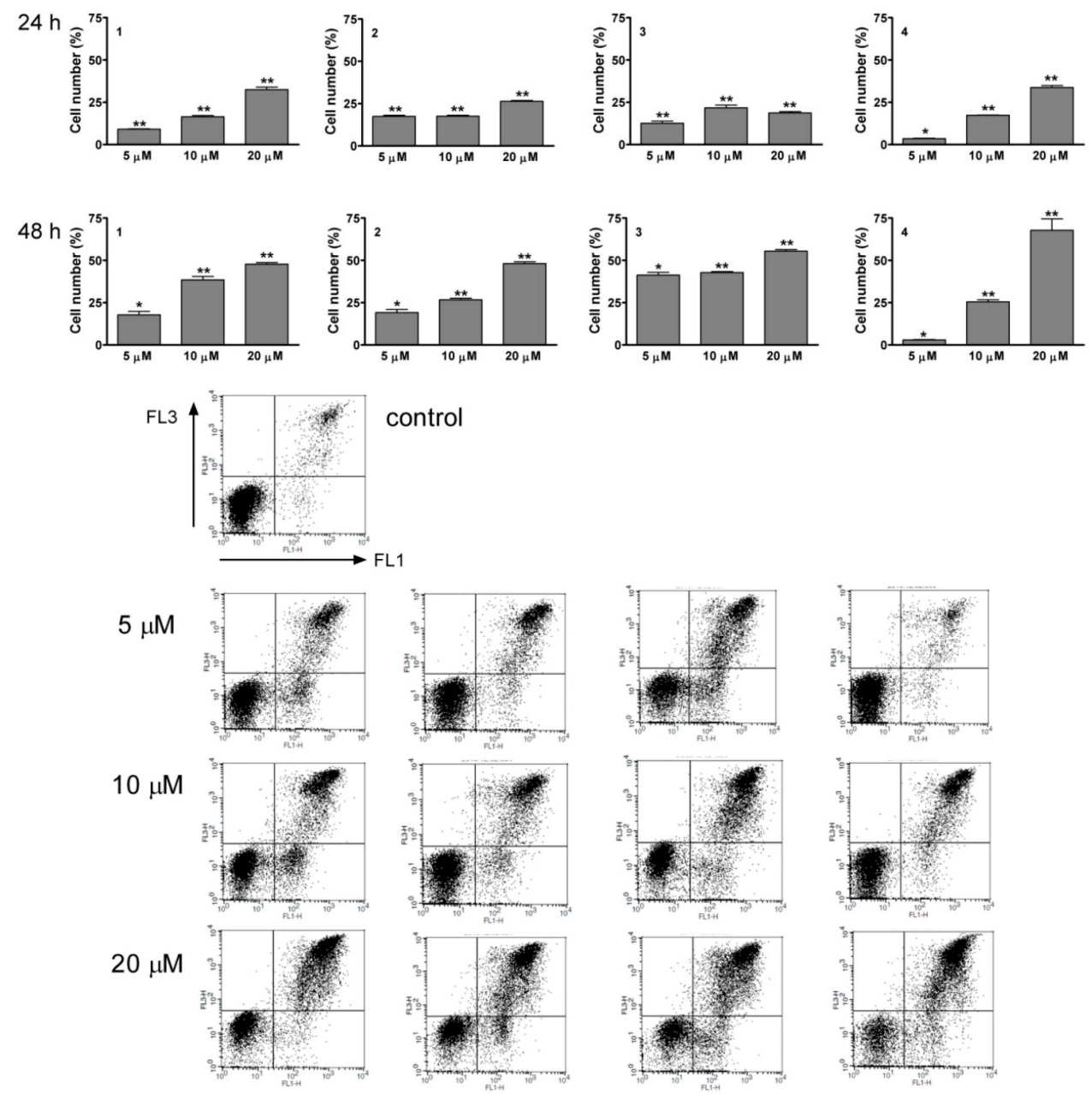

Figure 9. Proportion ofannexin V positivity after incubation with compounds 1-4 for 24 and $48 \mathrm{~h}$ (upper panels). ${ }^{*}$ and ${ }^{* *}$ denote $p<0.05$ and $p<0.01$, respectively, as compared with the control condition. Baseline values have been subtracted from treated values. Data are means \pm SEM from three determinations. Representative dot-plots from 48-h treatments (lower panels).

\subsection{RT-PCR Studies}

The mitochondria can be considered the central hub in the regulation of the apoptosis-survival balance. The intrinsic pathway of apoptosis is triggered by the release of cytochrome $\mathrm{c}$ and the subsequent recruitment of executionary proteins. This initiating function of the mitochondria is governed by the members of the Bcl-2 protein family, including antiapoptotic factors Bcl-2, Bcl-xl and Mcl-1 and the proapoptotic members Bax and Bak [19]. Bax and Bcl-2 are the most frequently investigated members of the family and their ratio is regarded as a descriptor of the actual apoptotic-survival state.

Sesquiterpenes $\mathbf{1}$ and $\mathbf{2}$ were selected for determination of the mRNA-level expression of these factors. A 24-h treatment with 1 resulted in an increase in the calculated ratio Bax/Bcl-2, which was found to be significant at $10 \mu \mathrm{M}$, while 2 elevated this ratio at $5 \mu \mathrm{M}$, but not at $10 \mu \mathrm{M}$ (Figure 10). Compounds 1 and $\mathbf{2}$ exhibited very similar $\mathrm{IC}_{50}$ values. Although the treatment-related activation 
of both caspases was less pronounced for 2 and the higher concentration elicited only a modest and nonsignificant change in the ratio $\mathrm{Bax} / \mathrm{Bcl}-2$, it could be concluded that this agent may induce non-apoptotic, caspase-independent cell death, especially at higher concentrations.

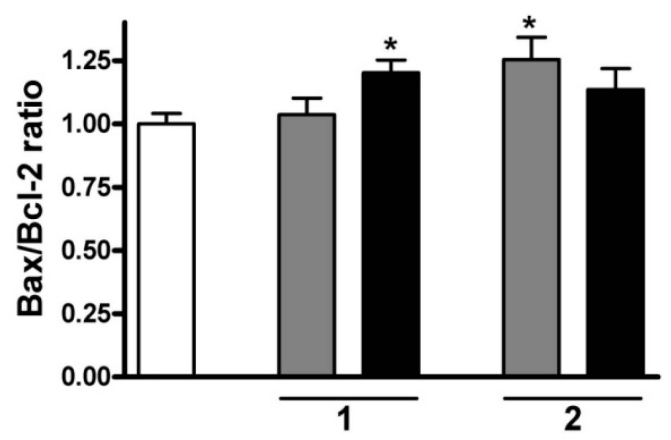

Figure 10. Calculated ratios Bax/Bcl-2 at an mRNA level after incubation with compound $\mathbf{1}$ or 2 for $24 \mathrm{~h}$. White, gray and black columns relate to the control, or 5 and $10 \mu \mathrm{M}$ sesquiterpene, respectively. ${ }^{*}$ denotes $p<0.05$, as compared with the control condition. Data are means \pm SEM from three determinations.

Since the cell cycle analysis results clearly indicate an arrest at the G2/M phase, the regulatory background of this blockade was additionally investigated. The multiplication of the cells is a highly complex procedure, involving a not yet completely described array of regulatory circuits. As concerns the G2/M phase transition, the complex formed by cyclin B1, B2 and cyclin-dependent kinase 1 (CDK1) plays a crucial role [20]. The mRNA-level expressions of these three factors were additionally determined after treatment for $24 \mathrm{~h}$ with $\mathbf{1}$ or $\mathbf{2}$. Both sesquiterpenes at $10 \mu \mathrm{M}$ decreased the expression of CDK1 and cyclin B2. The expression of cyclin B1 was increased by 1 while no considerable changes were detected after treatment with 2 (Figure 11). Many cell-cycle-governing proteins, including these two factors, are regulated by postsynthetic phosphorylation, and determination of the mRNA-level expression is therefore not the optimal approach for an exact description of their function. However, the effects of the sesquiterpenes on these factors may indicate that these natural products exert their antiproliferative action by disturbing the cell cycle machinery.

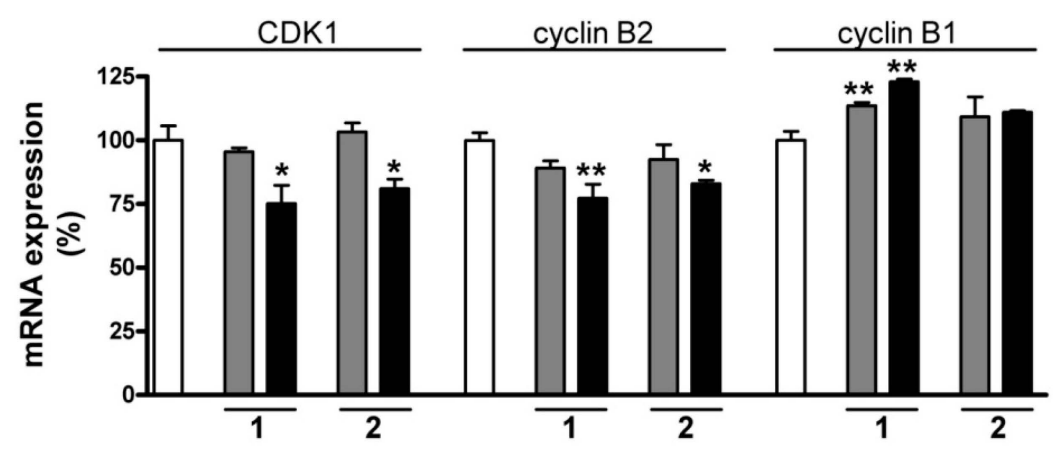

Figure 11. Expression of CDK1, cyclin B1 and cyclin B2 at the mRNA level after incubation with $\mathbf{1}$ or $\mathbf{2}$ for $24 \mathrm{~h}$. White, gray and black columns relate to the control, or 5 and $10 \mu \mathrm{M}$ sesquiterpene, respectively. * and ${ }^{* *}$ denote $p<0.05$ and $p<0.01$, respectively, as compared with the control condition. Data are means \pm SEM from three determinations.

The plant kingdom contains a virtually inexhaustible source of natural products with attractive pharmacological properties, which makes plant extracts suitable subjects for lead-finding studies. The predominance of drugs that have been developed from or inspired by natural products is especially true for anticancer agents. Such effective plant preparations may serve not only as the source of the active agent, but additionally as a safe and cost-effective means of chemoprevention [21]. 
The sesquiterpene lactones constitute a chemically diverse group of more than 5000 secondary metabolites, most of them isolated from Asteraceaea species. These natural products possess diverse biological activities, their anti-inflammatory and antiproliferative properties being the most characteristic [22]. Guaianolides and pseudoguaianolides are the subclasses of sesquiterpenes that exhibit the most pronounced cytotoxic effects, which are attributed to two main structural components: $\alpha$-methylene- $\gamma$-lactone and $\alpha, \beta$-unsaturated cyclopentanone rings [23]. These structural moieties, which function as alkylating agents reacting with sulfhydryl groups, are needed for antiproliferative action. This Michael-type addition involves various intracellular targets including mercaptyl groups of proteins, leading to the loss of enzyme activity [24]. The reaction also results in the depletion of free intracellular glutathione, disruption of the cellular redox balance and the consequent oxidative stress [25]. The generated reactive oxygen species have the capacity to activate the mitochondrial pathway of apoptosis [26]. Sesquiterpenes containing an epoxide ring besides the $\alpha$-methylene- $\gamma$-lactone pharmacophore can be regarded as bifunctional molecules and more pronounced antiproliferative action can be expected from them [24] Two of the currently investigated natural products, $\mathbf{1}$ and $\mathbf{2}$, are such sesquiterpenes. The consequences of the alkylation have been only incompletely elucidated, but one of the best-characterized sesquiterpenes with an anticancer effect is parthenolide, which directly inhibits NF- $\mathrm{kB}$ and also prevents the phosphorylation and subsequent degradation of $\mathrm{I} \kappa \mathrm{B}[27,28]$.

The terpenes are a "drug-like" subclass of natural compounds. Ingenol mebutate, found in Euphorbia peplus, has been registered for the treatment of premalignant lesions in actinic keratosis [29]. Orally active parthenolide derivatives have been prepared and proved selective against cancer stem cells [28]. The water-soluble dimethylaminohydrochloride derivative of the sesquiterpene arglabin is used in oncological practice in Kazakhstan [30]. All of our currently investigated effective molecules contain these critical pharmacophores, as an indication that they may be regarded as potential starting structures for the design and development of novel anticancer agents.

\section{Experimental Section}

\subsection{Chemicals}

The currently investigated sesquiterpene lactones 1-4 were isolated and identified as described earlier $[13,14]$. Their chemical structures are presented in Figure 1. All other chemicals, if otherwise not specified, were from Sigma-Aldrich (Budapest, Hungary).

\subsection{Cell Culturing and Antiproliferative Assay}

The human HL-60 promyelocytic leukemia cell line was purchased from the American Type Culture Collection (Manassas, VA, USA). Cells were grown in RPMI 1640 medium supplemented with $10 \%$ heat inactivated fetal calf serum (FCS), $1 \%$ L-glutamine, and $1 \%$ penicillin-streptomycin at $37^{\circ} \mathrm{C}$ in a humidified atmosphere containing $5 \% \mathrm{CO}_{2}$, using a Heraeus cytoperm 2 incubator (Heraeus, Vienna, Austria). Human skin fibroblasts (Sigma-Aldrich, Budapest, Hungary) were maintained in DMEM/F12 medium supplemented with 10\% FCS. All media and supplements were purchased from Gibco Life Technologies (Paisley, Scotland, UK). Cell counts were determined with a CC-110 microcellcounter (Sysmex, Kobe, Japan). Cells growing in the logarithmic phase of growth were used for all experiments described below.

The antiproliferative effects of 1-4 on HL-60 cells were determined by cell counting. Briefly, cells were seeded in $25-\mathrm{cm}^{2}$ tissue culture flasks at a density of 750,000 cells $/ 5 \mathrm{~mL}$ medium and the cells were exposed to the tested compound. After incubation periods of 24,48 and $72 \mathrm{~h}$, the cells were counted with a cell counter. All in vitro experiments were carried out on at least three parallel samples. Sigmoidal dose-response curves were fitted to the measured points and $\mathrm{IC}_{50}$ values were calculated by means of GraphPad Prism 4 software (GraphPad Software, San Diego, CA, USA). 


\subsection{Cell Viability Measurements}

The viability of HL-60 human leukemia cells and fibroblasts from healthy donors was determined by the colorimetric MTS assay (Promega, Madison, WI, USA) as described earlier [31]. Briefly, the cells (4000 HL-60 and 6000 fibroblasts) were seeded into 96-well plates in RPMI 10\% FCS and DMEM/F12 10\% FCS, respectively. Cells were cultured overnight before treatment. The effects of 1 and 2 at $0,0.1,0.3,1,3,10$ and $20 \mu \mathrm{M}$ were examined after a 72-h incubation. The MTS reagent (3-(4,5-dimethylthiazol-2-yl)-5-(3-carboxymethoxy-phenyl)-2-(4-sulfophenyl)-2H-tetrazolium) was applied to drug-treated and control $(0.2 \%$ DMSO) cells according to the manufacturer's protocol. Absorbance (at $490 \mathrm{~nm}$ ) was recorded on a multimode microplate reader (Perkin Elmer, Waltham, MA, USA). Viability was calculated relative to untreated control cells and blank wells containing media without cells.

\subsection{Cell Cycle Analysis by Flow Cytometry}

Cellular DNA content was measured by means of flow cytometric analysis, using the DNA-specific fluorescent dye PI. HL-60 cells $(200,000)$ were plated in 24-well tissue culture plates (Corning Life Sciences, Corning, NY, USA) in RPMI 10\% FCS and were treated with the indicated compound and concentrations on the graphs. After 24 or $48 \mathrm{~h}$ the cells were collected, washed with PBS and resuspended in DNA binding buffer $(1 \times$ PBS, $0.1 \%$ trisodium citrate, $10 \mu \mathrm{g} / \mathrm{mL}$ PI, $0.1 \% \mathrm{Tx}, 10 \mu \mathrm{g} / \mathrm{mL}$ RNaseA, (Sigma-Aldrich)). After $30 \mathrm{~min}$ incubation at room temperature cells were acquired on a FACSCalibur cytofluorimeter (Becton Dickinson, Franklin Lakes, NJ, USA), we gated out doublets for cell cycle analysis which was based on FL2-A/FL2-W dot plots, using ModFit software (Verity Software House, Topsham, ME, USA). Sub-G1 apoptotic population was analyzed on FL3 histograms using CellQuest software (Becton Dickinson) [32].

\subsection{Double Staining with Hoechst 33258 and PI}

Cells were seeded into a 6-well plate and incubated with various concentrations of the tested compounds for 24 or $48 \mathrm{~h}$. Hoechst 33258 and PI were added directly to the cells to give final concentrations of 5 and $3 \mu \mathrm{g} / \mathrm{mL}$, respectively. After incubation for $60 \mathrm{~min}$ at $37^{\circ} \mathrm{C}$, the cells were examined on a Nikon Fluorescence Microscope equipped with a Digital Sight Camera System, including appropriate filters for Hoechst 33258 and PI [33,34].

\subsection{Caspase-3 Assay}

The activity of caspase- 3 from treated cells was determined by means of a fluorimetric assay kit (Sigma-Aldrich Ltd., Budapest, Hungary). Ac-DEVD-AMC was used as substrate. In the course of the assay, the peptide substrate was cleaved by the enzyme, resulting in the release of AMC, which was determined on a microplate reader at $360 / 460 \mathrm{~nm}$ (excitation/emission). HL-60 cells were treated with the tested compounds at 5 and $10 \mu \mathrm{M}$ for $24 \mathrm{~h}$, untreated cells serving as control. The cells were harvested and incubated with cell lysis buffer (in proportion to the cell number) on ice for $15 \mathrm{~min}$. The cell lysate was centrifuged $(15 \mathrm{~min}, 17,000 \times \mathrm{g}$ ) and the supernatant was collected and analyzed. The results were expressed in fold increase of caspase- 3 activity relative to the result of the control condition [35].

\subsection{Caspase-9 Assay}

Caspase-9 activity was determined with a colorimetric assay kit (Sigma-Aldrich Ltd., Budapest, Hungary). Ac-LEHD- $p$ NA was used as substrate. The cleavage of the peptide substrate by caspase- 9 resulted in the release of $p \mathrm{NA}$, which was measured on a microplate reader at an absorbance wavelength of $405 \mathrm{~nm}$. All further conditions were identical with those in the caspase- 3 assay. 


\subsection{Reverse Transcription-Polymerase Chain Reaction (RT-PCR) Studies}

The actions of the investigated sesquiterpenes on the mRNA expression pattern of the markers of apoptosis, such as Bax, Bcl-2, cyclin-dependent kinase 1 (CDK1), cyclin B1 and cyclin B2, which play fundamental roles in the G2-M transition, were determined by RT-PCR in HL-60 cells. After a 24-h incubation period, the medium containing the tested natural products was discarded and the total RNA was isolated from the cells $\left(4 \times 10^{5}\right)$ by using the TRIzol Reagent according to the instructions of the manufacturer (Csertex Ltd., Budapest, Hungary). The pellet was resuspended in $100 \mu \mathrm{L}$ DNaseand RNase-free distilled water. The concentrations of RNA in the samples were determined from their absorbances at $260 \mathrm{~nm}$. The RNA $(0.5 \mu \mathrm{g})$ was mixed with DNase- and RNase-free distilled water and $20 \mu \mathrm{M}$ oligodT (Invitrogen, Carlsbad, CA, USA) in a final reaction volume of $10 \mu \mathrm{L}$, and incubation was performed at $70{ }^{\circ} \mathrm{C}$ for $5 \mathrm{~min}$. After the mixture had been cooled to $4{ }^{\circ} \mathrm{C}, 20 \mathrm{U} \mathrm{MMLV}$ reverse transcriptase (Promega, Madison, WI, USA), 20 U RNase inhibitor (Promega, Madison, WI, USA), $200 \mu \mathrm{M}$ dNTP (Sigma-Aldrich; Budapest, Hungary) in $50 \mathrm{mM}$ Tris-HCl, pH 8.3, $75 \mathrm{mM} \mathrm{KCl}$, and $5 \mathrm{mM} \mathrm{MgCl} 2$ in a final reaction volume of $10 \mu \mathrm{L}$ were added. The mixture was incubated at $37^{\circ} \mathrm{C}$ for $60 \mathrm{~min}$. The reaction was performed in the presence of $5 \mu \mathrm{L}$ cDNA, $12.5 \mu \mathrm{L}$ GoTaq Green Master Mix, $2 \mu \mathrm{L} 20$ pM sense and antisense primers of Bax, Bcl-2, CDK1 and cyclin B2 and $3.5 \mu \mathrm{L}$ DNase- and RNase-free distilled water. Human glyceraldehyde 3-phosphate dehydrogenase (hGAPDH) primers were used as internal control in all samples (Table 1). The reaction was performed with an ESCO SWIFT MAXI thermal cycler (Esco Technologies Inc., Philadelphia, PA, USA) and the products were separated on $2 \%$ agarose gels, marked with ethidium bromide and photographed under a UV transilluminator. Semiquantitative analysis was obtained by means of densitometric scanning of the gel with Kodak IMAGE STATION 2000R (Csertex Ltd., Budapest, Hungary) [36].

Table 1. Primers and PCR conditions of the determined genes, the Genebank access numbers and the length of PCR products.

\begin{tabular}{ccccc}
\hline Name & \multicolumn{1}{c}{ Primer Sequence } & Gene ID & Product Size (bp) & Coupling Temp. $\left({ }^{\circ} \mathbf{C}\right)$ \\
\hline CDK1 & $\begin{array}{c}\text { F: ACTGGCTGATTTGGCCTTGCC } \\
\text { R: TGAGTAACGAGCTGACCCCAGCAA }\end{array}$ & 983 & 118 & 62 \\
\hline cyclin B1 & $\begin{array}{c}\text { F: AATAAGGAGGGAGCAGTGCG } \\
\text { R: GAAGAGCCAGCCTAGCCTCAG }\end{array}$ & 891 & 51 & 60 \\
\hline cyclin B2 & $\begin{array}{l}\text { F: GCGTTGGCATTATGGATCG } \\
\text { R: TCTTCCGGGAAACTGGCTG }\end{array}$ & 9133 & 51 & 60 \\
\hline \multirow{2}{*}{ Bax } & $\begin{array}{l}\text { F: TGGCAGCTGACATGTTTTCTGAC } \\
\text { R: CGTCCCAACCACCCTGGTCT }\end{array}$ & 581 & 195 & 53 \\
\hline Bcl-2 & $\begin{array}{l}\text { F: GACTTCGCCGAGATGTCCAG } \\
\text { R: CAGGTGCCGGTTCAGGTACT }\end{array}$ & 596 & 225 & 51 \\
\hline hGAPDH & $\begin{array}{l}\text { F: ACCCAGAAGACTGTGGATGG } \\
\text { R: TGCTGTAGCCAAATTCGTTG }\end{array}$ & 2597 & 415 & 55 \\
\hline
\end{tabular}

\subsection{Flow Cytometric Apoptosis Assay}

HL-60 cells $(200,000)$ were plated in 24-well tissue culture plates in RPMI medium supplemented with $10 \%$ FCS and were treated with 1-4 in the concentrations indicated in the graphs. After 24 or $48 \mathrm{~h}$, the cells were collected and resuspended in Annexin V binding buffer (0.01 M HEPES, 0.14 M $\mathrm{NaCl}$ and $2.5 \mathrm{mM} \mathrm{CaCl}_{2}$ ). Annexin V-Alexa 488 (LifeTechnologies, Waltham, MA, USA) was added to the cells, which were then kept in the dark for $15 \mathrm{~min}$ at room temperature. Before the acquisition, PI $(10 \mu \mathrm{g} / \mathrm{mL})$ in annexin V binding buffer was added to diluted annexin V-Alexa 488 5-fold. Cells were analyzed on a FACSCalibur cytofluorimeter, using CellQuest software (Becton Dickinson, Franklin Lakes, NJ, USA). The percentages of the FL1 (annexin V-Alexa 488) positive and FL3 (PI) negative early-apoptotic cells and FL1 (annexin V-Alexa 488) positive and FL3 (PI) positive late-apoptotic cells were determined [37]. 


\subsection{Statistical Analysis}

All in vitro experiments were performed in triplicate and statistical analysis was carried out by ANOVA, followed by the Dunnett post-test with the use of GraphPad Prism 4 software (GraphPad Software, San Diego, CA, USA).

\section{Conclusions}

Overall, the presented results indicate that sesquiterpenes 1-4 exert antiproliferative action against HL-60 human leukemia cells. Although the sesquiterpenes are widely investigated compounds and their anticancer action is well recognized, similar results have not been published previously concerning 1-4. It was demonstrated that 1-4 elicited a concentration-dependent disturbance in the cell cycle and induced apoptosis by activating the mitochondrial pathway. The presented data indicate that these sesquiterpenes can be regarded as suitable structures for the development of novel potential anticancer agents.

Acknowledgments: The work of Judit Molnár was supported by an Aktion Österreich-Ungarn Universitatslehrerstipendien and Apáczai Csere János Doctoral Fellowship (A2-ACSJD-12). The financial support by the New Hungary Development Plan (TÁMOP-4.2.4 A/2-11-1-2012-0001) is gratefully acknowledged. The authors are grateful for financial support from the Hungarian Scientific Research Fund (OTKA K109293).

Author Contributions: Thomas Szekeres, Judit Hohmann and István Zupkó conceived and designed the study; Imre Ocsovszki and Philipp Saiko designed the experiments and interpreted the results. Judit Molnár drafted the manuscript. Judit Molnár, Gábor J. Szebeni, László G. Puskás, Boglárka Csupor-Löffler and Zsuzsanna Hajdú performed the experiments. All authors discussed the results, prepared and commented on the manuscript.

Conflicts of Interest: The authors declare no conflict of interest.

\section{References}

1. Are, C.; Rajaram, S.; Are, M.; Raj, H.; Anderson, B.O.; Chaluvarya Swamy, R.; Vijayakumar, M.; Song, T.; Pandey, M.; Edney, J.A.; et al. A review of global cancer burden: Trends, challenges, strategies, and a role for surgeons. J. Surg. Oncol. 2013, 107, 221-226. [CrossRef] [PubMed]

2. Cragg, G.M.; Grothaus, P.G.; Newman, D.J. Impact of natural products on developing new anti-cancer agents. Chem. Rev. 2009, 109, 3012-3043. [CrossRef] [PubMed]

3. Cragg, G.; Newman, D. Nature: A vital source of leads for anticancer drug development. Phytochem. Rev. 2009, 8, 313-331. [CrossRef]

4. Heywood, V.H.; Harborne, J.B.; Turner, B.L. The Biology and Chemistry of the Compositae; Academic Press: London, UK, 1977.

5. Hegnauer, R. Chemotaxonomie der Pflanzen; Birkhauser Verlag: Basel, Switzerland, 1989.

6. Kuete, V.; Sandjo, L.P.; Wiench, B.; Efferth, T. Cytotoxicity and modes of action of four Cameroonian dietary spices ethno-medically used to treat cancers: Echinops giganteus, Xylopia aethiopica, Imperata cylindrica and Piper capense. J. Ethnopharmacol. 2013, 149, 245-253. [CrossRef] [PubMed]

7. Csupor-Löffler, B.; Hajdú, Z.; Réthy, B.; Zupkó, I.; Máthé, I.; Rédei, T.; Falkay, G.; Hohmann, J. Antiproliferative activity of Hungarian Asteraceae species against human cancer cell lines. Part II. Phytother. Res. 2009, 23, 1109-1115. [CrossRef] [PubMed]

8. Réthy, B.; Csupor-Löffler, B.; Zupkó, I.; Hajdú, Z.; Máthé, I.; Hohmann, J.; Rédei, T.; Falkay, G. Antiproliferative activity of Hungarian Asteraceae species against human cancer cell lines. Part I. Phytother. Res. 2007, 21, 1200-1208. [CrossRef] [PubMed]

9. Csupor-Löffler, B.; Hajdú, Z.; Zupkó, I.; Molnár, J.; Forgo, P.; Vasas, A.; Kele, Z.; Hohmann, J. Antiproliferative constituents of the roots of Conyza canadensis. Planta Med. 2011, 77, 1183-1188. [CrossRef] [PubMed]

10. Hajdú, Z.; Zupkó, I.; Réthy, B.; Forgo, P.; Hohmann, J. Bioactivity-guided isolation of cytotoxic sesquiterpenes and flavonoids from Anthemis ruthenica. Planta Med. 2010, 76, 94-96. [CrossRef] [PubMed]

11. Kim, H.S.; Kundu, J.K.; Lee, J.S.; Oh, T.Y.; Na, H.K.; Surh, Y.J. Chemopreventive effects of the standardized extract (DA-9601) of Artemisia asiatica on azoxymethane-initiated and dextran sulfate sodium-promoted mouse colon carcinogenesis. Nutr. Cancer 2008, 60 (Suppl. 1), 90-97. [CrossRef] [PubMed] 
12. Lee, J.S.; Oh, T.Y.; Ahn, B.O.; Cho, H.; Kim, W.B.; Kim, Y.B.; Surh, Y.J.; Kim, H.J.; Hahm, K.B. Involvement of oxidative stress in experimentally induced reflux esophagitis and Barrett's esophagus: Clue for the chemoprevention of esophageal carcinoma by antioxidants. Mutat. Res. 2001, 480-481, 189-200. [CrossRef]

13. Hajdú, Z.; Hohmann, J.; Forgo, P.; Máthé, I.; Molnár, J.; Zupkó, I. Antiproliferative activity of Artemisia asiatica extract and its constituents on human tumor cell lines. Planta Med. 2014, 80, 1692-1697. [CrossRef] [PubMed]

14. Csupor-Löffler, B.; Zupkó, I.; Molnár, J.; Forgo, P.; Hohmann, J. Bioactivity-guided isolation of antiproliferative compounds from the roots of Onopordum acanthium. Nat. Prod. Commun. 2014, 9, 337-340. [PubMed]

15. Muhammad, I.; Takamatsu, S.; Mossa, J.S.; El-Feraly, F.S.; Walker, L.A.; Clark, A.M. Cytotoxic sesquiterpene lactones from Centaurothamnus maximus and Vicoa pentanema. Phytother. Res. 2003, 17, 168-173. [CrossRef] [PubMed]

16. Tolomeo, M.; Simoni, D. Drug resistance and apoptosis in cancer treatment: Development of new apoptosis-inducing agents active in drug resistant malignancies. Curr. Med. Chem. Anticancer Agents 2002, 2, 387-401. [CrossRef] [PubMed]

17. Kumar, S. Caspase function in programmed cell death. Cell Death Differ. 2007, 14, 32-43. [CrossRef] [PubMed]

18. Kuypers, F.A.; Lewis, R.A.; Hua, M.; Schott, M.A.; Discher, D.; Ernst, J.D.; Lubin, B.H. Detection of altered membrane phospholipid asymmetry in subpopulations of human red blood cells using fluorescently labeled annexin V. Blood 1996, 87, 1179-1187. [PubMed]

19. Brinkmann, K.; Kashkar, H. Targeting the mitochondrial apoptotic pathway: A preferred approach in hematologic malignancies? Cell Death Dis. 2014, 5, e1098. [CrossRef] [PubMed]

20. Lindqvist, A.; Kallstrom, H.; Lundgren, A.; Barsoum, E.; Rosenthal, C.K. Cdc25B cooperates with Cdc25A to induce mitosis but has a unique role in activating cyclin B1-Cdk1 at the centrosome. J. Cell Biol. 2005, 171, 35-45. [CrossRef] [PubMed]

21. Millimouno, F.M.; Dong, J.; Yang, L.; Li, J.; Li, X. Targeting apoptosis pathways in cancer and perspectives with natural compounds from Mother Nature. Cancer Prev. Res. 2014, 7, 1081-1107. [CrossRef] [PubMed]

22. Kreuger, M.R.; Grootjans, S.; Biavatti, M.W.; Vandenabeele, P.; D’Herde, K. Sesquiterpene lactones as drugs with multiple targets in cancer treatment: Focus on parthenolide. Anticancer Drugs 2012, 23, 883-896. [PubMed]

23. Fernandes, M.B.; Scotti, M.T.; Ferreira, M.J.; Emerenciano, V.P. Use of self-organizing maps and molecular descriptors to predict the cytotoxic activity of sesquiterpene lactones. Eur. J. Med. Chem. 2008, 43, 2197-2205. [CrossRef] [PubMed]

24. Gach, K.; Dlugosz, A.; Janecka, A. The role of oxidative stress in anticancer activity of sesquiterpene lactones. Naunyn Schmiedebergs Arch. Pharmacol. 2015, 388, 477-486. [CrossRef] [PubMed]

25. Zhang, S.; Won, Y.K.; Ong, C.N.; Shen, H.M. Anti-cancer potential of sesquiterpene lactones: Bioactivity and molecular mechanisms. Curr. Med. Chem. Anticancer Agents 2005, 5, 239-249. [CrossRef] [PubMed]

26. Gach, K.; Janecka, A. $\alpha$-Methylene- $\gamma$-lactones as a novel class of anti-leukemic agents. Anticancer Agents Med. Chem. 2014, 14, 688-694. [CrossRef] [PubMed]

27. Chadwick, M.; Trewin, H.; Gawthrop, F.; Wagstaff, C. Sesquiterpenoids lactones: Benefits to plants and people. Int. J. Mol. Sci. 2013, 14, 12780-12805. [CrossRef] [PubMed]

28. Ghantous, A.; Sinjab, A.; Herceg, Z.; Darwiche, N. Parthenolide: From plant shoots to cancer roots. Drug Discov. Today 2013, 18, 894-905. [CrossRef] [PubMed]

29. Doan, H.Q.; Gulati, N.; Levis, W.R. Ingenol mebutate: Potential for further development of cancer immunotherapy. J. Drugs Dermatol. 2012, 11, 1156-1157. [PubMed]

30. Shaikenov, T.E.; Adekenov, S.M.; Williams, R.M.; Prashad, N.; Baker, F.L.; Madden, T.L.; Newman, R. Arglabin-DMA, a plant derived sesquiterpene, inhibits farnesyltransferase. Oncol. Rep. 2001, 8, 173-179. [CrossRef] [PubMed]

31. Puskás, L.G.; Fehér, L.Z.; Vizler, C.; Ayaydin, F.; Rásó, E.; Molnár, E.; Magyary, I.; Kanizsai, I.; Gyuris, M.; Madácsi, R.; et al. Polyunsaturated fatty acids synergize with lipid droplet binding thalidomide analogs to induce oxidative stress in cancer cells. Lipids Health Dis. 2010, 9, 56. [CrossRef] [PubMed]

32. Vermes, I.; Haanen, C.; Reutelingsperger, C. Flow cytometry of apoptotic cell death. J. Immunol. Methods 2000, 243, 167-190. [CrossRef] 
33. Minorics, R.; Szekeres, T.; Krupitza, G.; Saiko, P.; Giessrigl, B.; Wölfling, J.; Frank, E.; Zupkó, I. Antiproliferative effects of some novel synthetic solanidine analogs on HL-60 human leukemia cells in vitro. Steroids 2011, 76, 156-162. [CrossRef] [PubMed]

34. Ribble, D.; Goldstein, N.B.; Norris, D.A.; Shellman, Y.G. A simple technique for quantifying apoptosis in 96-well plates. BMC Biotechnol. 2005, 5, 12. [CrossRef] [PubMed]

35. Molnár, J.; Ocsovszki, I.; Puskás, L.; Ghane, T.; Hohmann, J.; Zupkó, I. Investigation of the antiproliferative action of the quinoline alkaloids kokusaginine and skimmianine on human cell lines. Curr. Signal Transduct. Ther. 2013, 8, 148-155. [CrossRef]

36. Molnár, J.; Frank, É.; Minorics, R.; Kádár, Z.; Ocsovszki, I.; Schönecker, B.; Wölfling, J.; Zupkó, I. A click approach to novel D-ring-substituted 16a-triazolylestrone derivatives and characterization of their antiproliferative properties. PLoS ONE 2015, 10, e0118104. [CrossRef] [PubMed]

37. Nagy, L.I.; Fehér, L.Z.; Szebeni, G.J.; Gyuris, M.; Sipos, P.; Alföldi, R.; Ózsvári, B.; Hackler, L.; Balázs, A.; Batár, P.; et al. Curcumin and its analogue induce apoptosis in leukemia cells and have additive effects with bortezomib in cellular and xenograft models. Biomed. Res. Int. 2015, 2015, 968981. [CrossRef] [PubMed]

(C) 2016 by the authors; licensee MDPI, Basel, Switzerland. This article is an open access article distributed under the terms and conditions of the Creative Commons by Attribution (CC-BY) license (http://creativecommons.org/licenses/by/4.0/). 